\title{
Spatiotemporal variation and trends in rainfall erosivity in China's dryland region during 1961-2012
}

\author{
Fengbo Yang a,b, Changhe $\mathrm{Lu}^{\mathrm{a}, *}$ \\ ${ }^{a}$ Key Laboratory of Land Surface Pattern and Simulation, Institute of Geographic Sciences and Natural Resources Research, Chinese Academy of Sciences, Beijing 100101, China \\ ${ }^{\mathrm{b}}$ University of Chinese Academy of Sciences, Beijing 100049, China
}

\section{A R T I C L E I N F O}

\section{Article history:}

Received 11 September 2014

Received in revised form 29 April 2015

Accepted 9 June 2015

Available online 19 June 2015

Keywords:

Rainfall erosivity

Spatiotemporal variation

Trend

China's dryland region

\begin{abstract}
A B S T R A C T
This study evaluated rainfall erosivity and its changes in China's dryland region during 1961-2012, using a daily rainfall erosivity model, ArcGIS based spatial interpolation tools, and the Mann-Kendall and Sen's methods. It was found that mean rainfall erosivity was $2-4098 \mathrm{MJ} \mathrm{mm} \mathrm{ha} \mathrm{m}^{-1} \mathrm{~h}^{-1} \mathrm{a}^{-1}$ in the region, with the regional average of $794 \mathrm{MJ} \mathrm{mm} \mathrm{ha} \mathrm{m}^{-1} \mathrm{~h}^{-1} \mathrm{a}^{-1}$, showing a significant increase trend accordingly with an increase in rainfall from northwest to southeast. Rainfall erosivity varied annually with the CV of $32.4-491.3 \%$, and varied seasonally with about three-quarter distributed in summer. During 1961-2012, a statistically significant increase/decrease trend in rainfall erosivity was detected only for $24 / 10$ stations or about $4.6 / 0.4 \%$ of the region, and a nonsignificant increase/decrease trend was observed for $32 / 45$ stations or $16.5 / 10.0 \%$ of the region at the 50 to $90 \%$ confidence level. No statistically confidential trend was found for other 126 stations or $68.5 \%$ of the region. At regional level, mean annual erosivity of the arid zone indicated an upward trend, while the sub-humid zone a downward, but the semi-arid zone generally had no evidential trend. Comparing the 26 year's averages during 1987-2012 and 1961-1986, mean erosivity of the arid zone increased by 17.4\%, the sub-humid zone decreased by $6.1 \%$, and the semi-arid zone reduced slightly by $0.45 \%$. The results suggest that change in the rainfall characteristics during the past half century had no significant influence on water erosion in the majority of the region, but it could probably induce an increase of water erosion risk in parts of the drier west and a slight decrease in parts of the wetter east including the Loess Plateau.
\end{abstract}

(c) 2015 Elsevier B.V. All rights reserved.

\section{Introduction}

Water erosion causes environmental degradation (Lee and Heo, 2011; Xin et al., 2011) and is affected by natural and human factors involved in climate, terrain, soil, land use and management. During the past decades, the global and regional climate has shown various changes (IPCC, 2013). For precipitation, various changes have been observed in the amount, frequency and intensity (Back et al., 2011; Petkovšek and Mikoš, 2004). These changes influence erosivity of rainfall, and thus water erosion (Bazzano et al., 2010; Bonilla and Vidal, 2011; Busnelli et al., 2006). In the context of climate change, the effect of altered rainfall characteristics on soil erosion is one of the main concerns of soil conservation studies (Angulo-Martinez and Begueria, 2009).

Various indices have been developed to quantify rainfall erosivity, among which the R-factor of the Universal Soil Loss Equation (USLE) or its revised version, RUSLE (Renard et al., 1997), is the most widely used one (Diodato and Bellocchi, 2009). The R-factor is calculated

\footnotetext{
* Corresponding author at: Institute of Geographic Sciences and Natural Resources Research, Chinese Academy of Sciences (IGSNRR-CAS), 11 A, Datun Road, Chaoyang District, Beijing 100101, China.

E-mail address: luch@igsnrr.ac.cn (C. Lu).
}

from the $\mathrm{EI}_{30}$ index using continuous rainfall data series with a time resolution of at least $15 \mathrm{~min}$, and needs more than 20 years of rainfall data to obtain the mean annual value as to lessen the impact of natural climatic variations (Weiss, 1964; Wischmeier and Simth, 1958, 1978). Due to lack of rainfall process data, this method is seldom used to estimate rainfall erosivity in long-term trend or at large scale (Meusburger et al., 2012). As an alternative, simple algorithms have been used to predict rainfall erosivity from routine meteorological records of annual (Lee and Heo, 2011), monthly (Loureiro and Coutinho, 2001; Renard and Freimund, 1994), and daily (Yu and Rosewell, 1996; Zhang et al., 2002) rainfall data. In these algorithms, rainfall erosivity is calculated as an exponential (Richardson, 1983), linear (Lo et al., 1985) or logarithmic (Wischmeier and Smith, 1965) function of rainfall amount. Daily rainfall data can adequately present the rainfall variation characteristics and are usually available, and thus are preferably used to estimate rainfall erosivity (Angulo-Martinez and Begueria, 2009).

Detection of long-term trend in rainfall erosivity can provide information on the potential influence of rainfall changes on soil erosion. It is particularly useful for dryland areas, which are more sensitive to water erosion, and to climate changes (Feng and Fu, 2013; Huang et al., 2012) because of their fragile biophysical conditions. In China's dryland region, various changes have been observed in temperature, 
precipitation and other climatic factors during the past decades (Fan et al., 2012; Ge et al., 2013; Meng et al., 2013; Wang et al., 2006; Zhao, 2013). Many studies analyzed the effect of recent climate changes on droughts (Yao et al., 2013), stream runoff (Wang et al., 2012; Zhang et al., 2013), plant phonological development (Dai et al., 2012, 2014; Ge et al., 2013), and plant productivity (He et al., 2014; Xiao et al., 2013; Yao et al., 2012) in parts of the region. Some studies analyzed changes in rainfall erosivity, indicating that the rainfall erosivity tended to increase in north Xinjiang and north Tibet Plateau, but to decrease in the Loess Plateau (Liu et al., 2013; Xin et al., 2011; Zhang et al., 2003). These studies provided useful information on the variation of rainfall erosivity, but a further analysis is necessary for the region as a whole. This study has three aims: the first is to estimate the rainfall erosivity from daily rainfall data, the second is to analyze its spatiotemporal variation, and the third is to detect the trend of annual erosivity during 1961-2012. Spatial interpolation and GIS methods were used to map the spatial distribution of rainfall erosivity in China's dryland region.

\section{Data and methods}

\subsection{Study area}

The dryland region of China was delineated approximately based on the $600 \mathrm{~mm}$ isohyet of annual precipitation, taking into account the integrity of terrain units such as the Loess Plateau, a well-known region by its severe water erosion. The region extends between $69.4-128.0^{\circ} \mathrm{E}$ and $27.2-51.1^{\circ} \mathrm{N}$ with an area of 5.58 million $\mathrm{km}^{2}$, about $60 \%$ of China's territory. It covers the Tibet Plateau, the Loess Plateau and the Inner Mongolia Plateau, involved in 12 provincial administrative units including the whole/most part of Xinjiang, Qinghai, Xizang (Tibet), Ningxia, Inner Mongolia, Gansu, Shaanxi, Shanxi, Hebei and Beijing, and a small part of Henan, Jilin and Liaoning (Fig. 1).

The region has a monsoon climate characterized by a distinct seasonal variation. The mean annual temperature is between -3.7 and $13.6^{\circ} \mathrm{C}$, and the regional average is $7.1^{\circ} \mathrm{C}$ with the monthly temperature ranged from $21.0^{\circ} \mathrm{C}$ in July to $-9.4^{\circ} \mathrm{C}$ in January. The mean annual precipitation is $33-623 \mathrm{~mm}$, of which $61.8-76.1 \%$ is distributed in the rainy season from June to September. Based on the aridity index (K), the ratio of annual precipitation to annual potential evapotranspiration ( $\mathrm{Ci}$ and Wu, 1997; Thornthwaite, 1948), the study area was divided into arid $(\mathrm{K}<0.2)$, semi-arid $(0.2 \leq \mathrm{K}<0.5)$ and sub-humid $(\mathrm{K} \geq 0.5)$ zones (Fig. 1). The arid zone including the hyper-arid has an annual precipitation generally less than $200 \mathrm{~mm}$, covering the major part of Xinjiang, northwestern Tibet Plateau and western Inner Mongolia. The semiarid zone has an annual precipitation normally between 200 and $450 \mathrm{~mm}$, covering south central Tibet Plateau, northwestern Loess Plateau, eastern Inner Mongolia, and northern Xinjiang. The sub-humid region is distributed in the eastern, northeastern and southeastern part with an annual precipitation mostly above $450 \mathrm{~mm}$, including east and south parts of the Loess Plateau, southeastern Tibet Plateau, and northern part of the North China Plain. Water erosion is serious in the hilly areas of the sub-humid and semi-arid zones, but it is weak in the

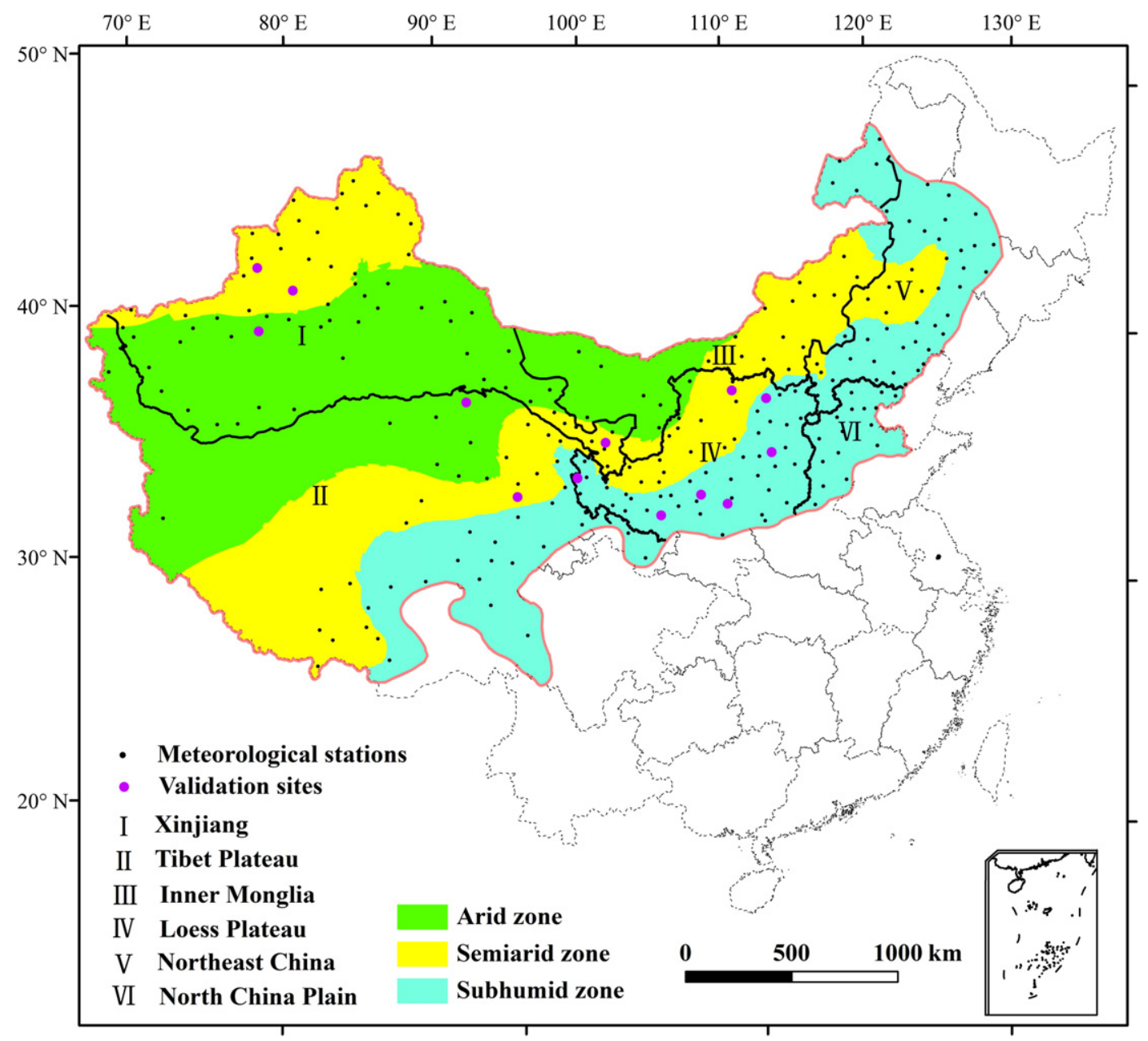

Fig. 1. Location of meteorological stations, major land units and climate zones in the study area. 
arid zone particularly the hyper-arid part including the Taklimakan Desert, where wind erosion and soil salinization are the major problems of land degradation.

\subsection{Rainfall data and the homogeneity check}

The collected data include: 1) daily precipitation data during 1961-2012 from the National Meteorological Information Centre of China (http://cdc.cma.gov.cn) for 298 stations in the region (Fig. 1); and 2) 60-min rainfall data during 1981-1988 at 13 representative stations (Table 1; Fig. 1), and 30- and 60-min rainfall data for 599 storms at 79 sites during 1981-1988 from the China's Hydrological Yearbook, which are used to evaluate the estimated rainfall erosivity from daily data.

In this study, the evaluation of rainfall erosivity was based only on rainfall data, and thus the snow and hail records were excluded from the daily observation data at all stations. The years with one or more months of missing records were excluded for the analysis. By a systematic check using a batch program based on the Matlab software, 237 stations had complete records for the study period from 1961 to 2012, and 8 for $50-51$ years, 12 for $40-48$ years, 12 for 30-39 years, 24 for 20-28 years, 4 for $10-14$ years and 1 for 7 years. The stations with observation span of less than 20 years are located in the arid western part where meteorological stations are sparsely distributed.

To detect trend in rainfall erosivity, the rainfall data should be consistently recorded at a station without changes in the location and the general surroundings, the observation equipment, and the method of data collection during the observation period, as the changes can result in inhomogeneity of data records (Khaliq and Ouarda, 2007). In this study, the Standard Normal Homogeneity Test (Alexandersson, 1986), a location specific homogeneity test, was applied to examine the consistence of rainfall data. This test assumes that the data collected at all sites within a same climatic region should be highly correlated, have similar variability, and differ only by scaling factors and random sampling variability (Costa and Soares, 2009), therefore, homogeneity of a data series can be checked by comparing with a single or multiple reference series (Toreti et al., 2011). For rainfall records at each of the 298 stations, the homogeneity was examined by comparing the annual rainfall value with four highly correlated reference series from the surrounding stations, following the procedure in literature (Jiang et al., 2008; Khaliq and Ouarda, 2007; Liu and Sun, 1995). In total, 290 stations have passed the homogeneity test, of which 237 stations have a similar duration of 50-52 years, and were used for the trend analysis of annual erosivity.

\subsection{Model of rainfall erosivity}

Annual rainfall erosivity was estimated for each of the 298 stations from daily rainfall data using the method of Zhang et al. (2002), which was well tested and widely used in China (Xin et al., 2011; Zhang et al., 2003). This method was derived from the Richardson (1983)

Table 1

General information of 13 stations at which 60-min rainfall data were collected for 19811988.

\begin{tabular}{lrrrr}
\hline Station & Lon. $\left({ }^{\circ}\right)$ & Lat. $\left({ }^{\circ}\right)$ & Elevation $(\mathrm{m})$ & Annual precipitation $(\mathrm{mm})$ \\
\hline Yamadu & 81.80 & 43.60 & 770 & 237 \\
Xinquman & 82.72 & 41.03 & 1029 & 60 \\
Bayinbuluge & 84.13 & 43.00 & 2435 & 253 \\
Dangchengwan & 94.90 & 39.50 & 1375 & 160 \\
Xiangride & 98.13 & 35.75 & 3441 & 260 \\
Dongjiazhuang & 101.27 & 36.67 & 2636 & 419 \\
Shiyanghe & 102.73 & 38.18 & 1470 & 136 \\
Renda & 105.75 & 35.17 & 1380 & 462 \\
Qingyang & 107.88 & 36.00 & 1096 & 489 \\
Huangling & 109.27 & 35.58 & 829 & 594 \\
Longtouguai & 109.78 & 40.30 & 1050 & 260 \\
Qingshuihe & 111.68 & 39.90 & 1096 & 365 \\
Chakou & 111.78 & 37.63 & 1120 & 490
\end{tabular}

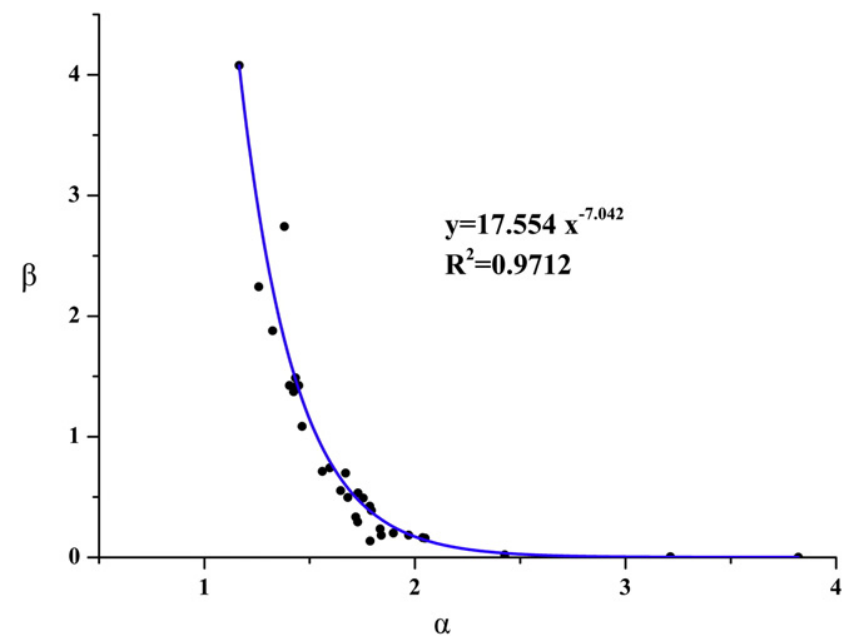

Fig. 2. Relationship between coefficients $\alpha$ and $\beta$. Data source: Zhang et al., 2002.

equation, $\mathrm{EI}=\alpha P^{\beta}$, where $\mathrm{EI}$ is an event's erosivity and $P$ is the rainfall, with the equation below to calculate half-month rainfall erosivity, $R$ (MJ mm ha ${ }^{-1} \mathrm{~h}^{-1}$ ):

$R=\alpha \sum_{j=1}^{\mathrm{k}}\left(P_{j}\right)^{\beta}$

where $P_{j}$ is the erosive rainfall ( $\mathrm{mm}$ ) for day $j$ in a given half-month of $\mathrm{k}$ days, and $\alpha$ and $\beta$ are coefficients. For daily rainfall equal to or larger than the threshold value of $12 \mathrm{~mm}, P_{j}$ is the actual rainfall, otherwise $P_{j}$ equals 0 (Xie et al., 2000). The annual erosivity is the summation of all half-month erosivity during the year.

The $\beta$ varied with changes in rainfall characteristics, and was estimated with the empirical equation below (Zhang et al., 2002):

$\beta=0.8363+\frac{18.144}{P_{d 12}}+\frac{24.455}{P_{y 12}}$

where $P_{d 12}$ and $P_{y 12}$ are the average daily and annual rainfall for days with rainfall $\geq 12 \mathrm{~mm}$, respectively.

Zhang et al. (2002) formulated an exponential equation to obtain the $\alpha$ value from the estimated $\beta$, based on the data obtained from 71 representative sites in whole China. In this study, we selected the $\alpha$ and $\beta$ data pairs at 33 stations that are located in our study area (Fig. 2), and then reformulated the equation in the form below:

$\alpha=17.554 \beta^{-7.042}$.
Table 2

General description of validation statistics.

$$
\begin{aligned}
& \text { 1) Mean relative bias error: } M R B E=\sum_{i=1}^{n}\left(D_{i}-C_{i}\right) / \sum_{i=1}^{n} C_{i} \times 100 \\
& \text { 2) Mean relative absolute error: } M R A E=\sum_{i=1}^{n}\left|D_{i}-C_{i}\right| / \sum_{i=1}^{n} C_{i} \times 100 \\
& \text { 3) Root mean square error: } R M S E=\sqrt{\sum_{i=1}^{n}\left(D_{i}-C_{i}\right)^{2} / n} \\
& \text { 4) Coefficient of determination: } \\
& \mathrm{R}^{2}=\left[\frac{\sum_{i=1}^{n}\left(D_{i}-M D\right) \times\left(C_{i}-M C\right)}{\sqrt{\sum_{i=1}^{n}\left(D_{i}-M D\right)^{2} \times \sum_{i=1}^{n}\left(C_{i}-M C\right)^{2}}}\right]^{2}
\end{aligned}
$$

Where $n$ is the number of years. $D_{i}$ is the erosivity in year $i$ and MD the average annual erosivity from daily rainfall data, and $C_{i}$ is the erosivity in year $i$ and $M C$ the average annual erosivity from 60-min rainfall data. 

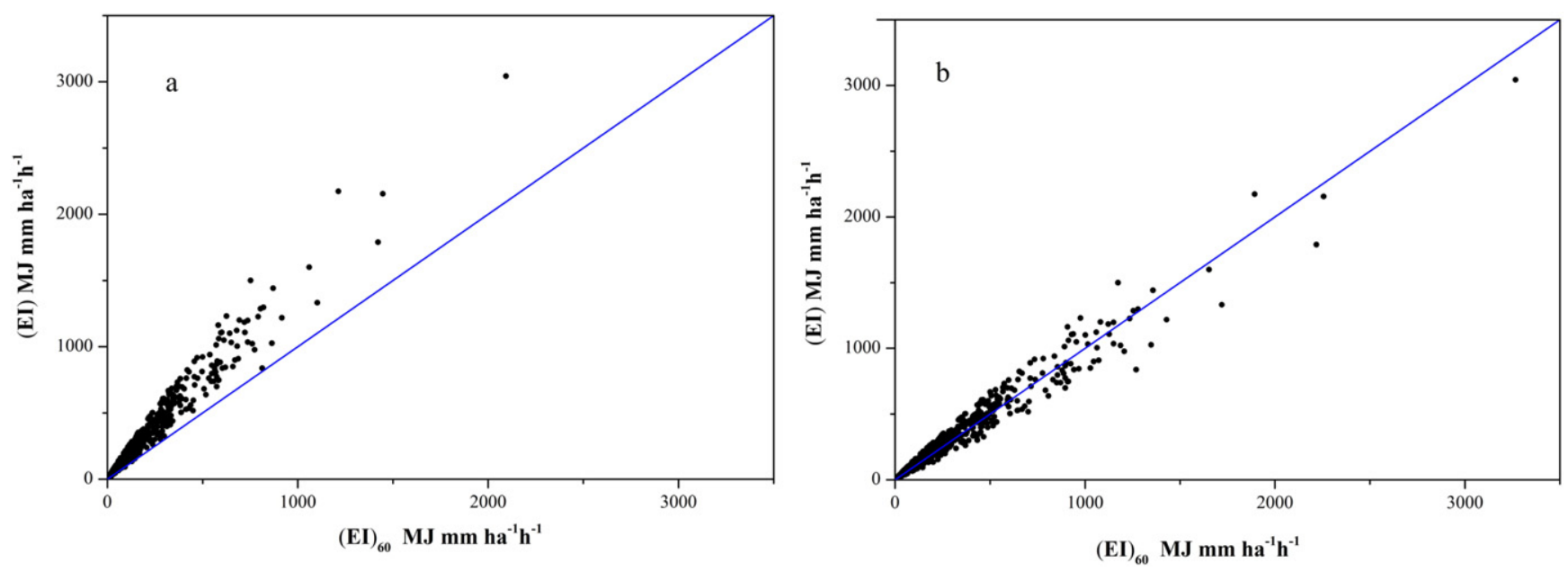

Fig. 3. Relationship between event's erosivity values of EI and (EI) 60 (a) and the adjusted (EI) 60 (b) for the 599 storms.

\subsection{Model evaluation}

The daily erosivity model was evaluated at 13 representative stations (Table 1 ), with four validation statistics (Table 2 ), including mean relative bias error (MRBE), mean relative absolute error (MRAE), root mean square error (RMSE), and coefficient of determination $\left(R^{2}\right)$.

The yearly erosivity for the model validation was calculated from the classic EI index approach using 60-min interval data of erosive rainfall events. With this coarse time resolution data, the rainfall intensity and thus the storm erosivity are often substantially underestimated. Therefore, many researchers have suggested a conversion coefficient to reduce the bias error (Renard et al., 1997; Weiss, 1964; Zhu et al., 2011) based on higher time resolution data from continuous records of rainfall intensity. Denoted this coefficient as $c$, the individual storm erosivity, EI, was computed with the equation below:

$\mathrm{EI}=c(\mathrm{EI})_{60}$

where $(\mathrm{EI})_{60}$ is the erosivity of an erosive event with the accumulative rainfall of larger than $12.7 \mathrm{~mm}$ (Renard et al., 1997), as computed from 60 -min interval data. The variable I $\left(\mathrm{mm} \mathrm{h}^{-1}\right)$ is the maximum 30-min rainfall intensity, taking the maximum hourly rainfall of the storm, and $\mathrm{E}\left(\mathrm{MJ} \mathrm{ha}^{-1}\right)$ is the total kinetic energy, as calculated using the Brown and Foster equation (1987) in the form below (Forster, 2004):

$E=\sum_{k=1}^{\mathrm{m}} 0.29\left[1-0.72 \exp \left(-0.082 i_{k}\right)\right](\Delta V)_{k}$ where $\mathrm{m}$ is the number of 60-min intervals during an erosive rainfall event, $i_{k}$ is the rainfall intensity $\left(\mathrm{mm} \mathrm{h}^{-1}\right)$, and $\Delta V_{k}$ is the rainfall depth ( $\mathrm{mm}$ ) during time period $k$. The annual erosivity is the summation of all event's erosivity occurred during the year. The coefficient $c$ was obtained by linear regression, based on the event's erosivity values of 599 storms, as calculated from 30- and 60-min interval data, respectively.

\subsection{Mean annual rainfall erosivity and its spatiotemporal variation}

Mean annual rainfall erosivity at each of the 298 sites was simply calculated by averaging the annual values of observation years, without considering difference in the duration. Based on these site's values, the spatial distribution of mean annual erosivity was interpolated with the high accuracy surface modeling (HASM) tool (Yue et al., 2004). Different from the Kriging and Inverse Distance Weighted (IDW) methods with an assumed homogeneous stochastic field (Yue, 2010), the HASM takes into account the non-homogeneity caused by topographic and locational factors, and thus has a relatively low reliance on the information of sampling points (Zhao, 2013). In this study, the rainfall erosivity at all stations was interpolated by a quadratic polynomial equation, taking into account the influence of latitude, longitude, elevation and slope. A stepwise regression was used to select the independent variables, and a multicollinearity analysis of the variables was conducted to ensure that there is no linear relationship between two selected variables. The residual was rectified by the HASM model with fitting result and information of the sites. Based on the interpolated

Table 3

Annual rainfall erosivity (MJ mm ha ${ }^{-1} \mathrm{~h}^{-1} \mathrm{a}^{-1}$ ) from daily and 60-min rainfall data and the validation results.

\begin{tabular}{|c|c|c|c|c|c|c|c|c|}
\hline \multirow[t]{2}{*}{ Hydrological site } & \multicolumn{2}{|c|}{ Erosivity from daily data } & \multicolumn{2}{|c|}{$\begin{array}{l}\text { Erosivity from 60-min } \\
\text { data }\end{array}$} & \multirow[t]{2}{*}{$\mathrm{R}^{2}$} & \multirow[t]{2}{*}{$\begin{array}{l}\text { MRBE } \\
(\%)\end{array}$} & \multirow[t]{2}{*}{$\begin{array}{l}\text { MRAE } \\
(\%)\end{array}$} & \multirow[t]{2}{*}{$\begin{array}{l}\text { RMSE } \\
\left(\mathrm{MJ} \mathrm{mm} \mathrm{ha} \mathrm{m}^{-1} \mathrm{~h}^{-1}\right)\end{array}$} \\
\hline & Mean & Range & Mean & Range & & & & \\
\hline Yamadu & 65 & $0-159$ & 77 & $0-191$ & 0.93 & -15.84 & 21.3 & 24.8 \\
\hline Xinquman & 59 & $21-176$ & 66 & $0-356$ & 0.82 & -10.30 & 35.1 & 32.1 \\
\hline Bayinbuluge & 91 & $0-173$ & 87 & $7-445$ & 0.88 & 4.48 & 23.8 & 23.1 \\
\hline Dangchengwan & 232 & $232-472$ & 203 & $16-252$ & 0.81 & 14.63 & 38.6 & 90.7 \\
\hline Xiangride & 70 & $0-118$ & 62 & $7-221$ & 0.46 & 12.10 & 34.6 & 32.0 \\
\hline Dongjiazhuang & 407 & $111-604$ & 297 & $82-483$ & 0.88 & 30.67 & 22.4 & 107.4 \\
\hline Shiyanghe & 77 & $77-110$ & 60 & $24-56$ & 0.94 & 21.67 & 36.9 & 22.7 \\
\hline Renda & 707 & $167-1249$ & 654 & $48-1111$ & 0.96 & 11.41 & 13.6 & 113.3 \\
\hline Qingyang & 1018 & $558-2413$ & 1002 & $342-2340$ & 0.92 & 4.78 & 10.0 & 125.6 \\
\hline Huangling & 1465 & $570-2456$ & 1659 & $759-3612$ & 0.86 & 2.77 & 14.9 & 230.0 \\
\hline Longtouguai & 532 & $83-980$ & 624 & $188-1175$ & 0.93 & -12.31 & 15.5 & 126.4 \\
\hline Qingshuihe & 627 & $232-1008$ & 601 & 194-1061 & 0.97 & 7.54 & 11.3 & 96.0 \\
\hline Chakou & 1279 & $723-2239$ & 1021 & 647-1729 & 0.84 & 28.60 & 22.8 & 347.2 \\
\hline
\end{tabular}




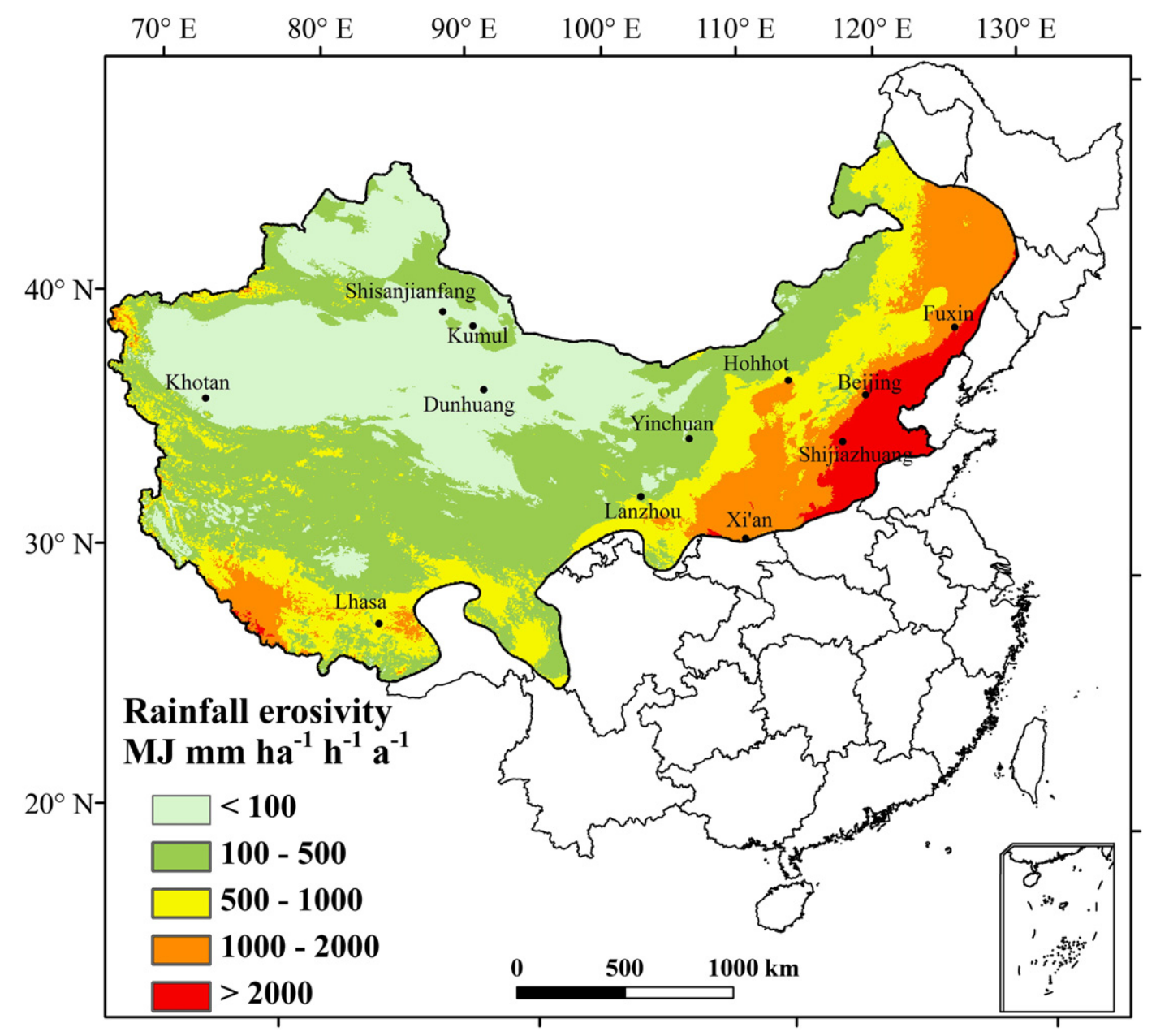

Fig. 4. Spatial distribution of mean annual rainfall erosivity in the study area.

results, the regional average of mean annual erosivity was obtained by averaging the grid value using the Geostatistical Analyst tool in ArcGIS.

For a specific year, the regional mean value was calculated by averaging the yearly erosivity at the 237 stations that have same time span from 1961 to 2012. Seasonal (monthly) distribution of annual erosivity was expressed in percent of seasonal (monthly) erosivity as the annual total. Annual variation was indicated by coefficient of variation (CV), presented as a percentage of the standard deviation of annual erosivity to the mean value of observation years. The spatial distribution of $\mathrm{CV}$ was interpolated with the IDW approach based on the values at the 290 stations with homogeneous data records. Compared to the interpolation result by Kriging method, the IDW described the spatial variation comparatively well in this study.

\subsection{Trend analysis and estimation of change rate}

The trend of annual rainfall erosivity was detected with the nonparametric Mann-Kendall test, and the trend magnitude was estimated

Table 4

Regional mean annual rainfall and erosivity for the whole region and the three climatic zones.

\begin{tabular}{lcccl}
\hline Zones & $\begin{array}{l}\text { Rainfall } \\
(\mathrm{mm})\end{array}$ & $\begin{array}{l}\text { Erosive } \\
\text { rainfall }(\mathrm{mm})\end{array}$ & $\begin{array}{l}\text { Rainfall erosivity } \\
\left(\mathrm{MJ} \mathrm{mm} \mathrm{ha} \mathrm{m} \mathrm{h}^{-1}\right)\end{array}$ & $\begin{array}{l}\text { Ratio of erosivity } \\
\text { to rainfall }\end{array}$ \\
\hline Arid zone & 80 & 24 & 97 & 1.21 \\
Semi-arid zone & 283 & 114 & 407 & 1.44 \\
Sub-humid zone & 483 & 267 & 1372 & 2.84 \\
Whole region & 333 & 172 & 794 & 2.38 \\
\hline
\end{tabular}

with the nonparametric Sen's method (Gilbert, 1987). The evaluation was based on the Excel template application MAKESENS, as developed by Salmi et al. (2002) for estimating trends in the time series of annual atmospheric and precipitation pollutant concentrations.

The Mann-Kendall test is widely used to identify trends in time series (Kendall, 1975; Mann, 1945), such as long-term climatic and hydrological data (Beran et al., 1996; Burn and Elnur, 2002; Sicard et al., 2010). It is based on two statistic variables $S$ and $Z$ to determine whether a time series of $n$ data points has a significant trend. The $S$ is the summation of $\operatorname{sgn}\left(x_{i+1}-x_{i}\right)$ that has a value of 1 for data point value $x_{i}$ is less than $x_{i+1}, 0$ for $x_{i}=x_{i+1}$, and -1 for $x_{i}>x_{i+1}(i=1,2 \ldots n-1)$. The $\mathrm{Z}$ is the standardized test statistic of $S$, which equals zero for $S=0$, $(S-1) /[\operatorname{var}(S)]^{0.5}$ for $S>0$, and $(S+1) /[\operatorname{var}(S)]^{0.5}$ for $S<0$, where $\operatorname{var}(S)$ is the variance of $S$ (Salmi et al., 2002). A positive (negative) value of $Z$ indicates an upward (downward) trend. At $\sigma$ level of significance, a null hypothesis is rejected if the absolute $Z$ value is greater than $Z_{1}-\sigma / 2$, where $Z_{1}-\sigma / 2$ is obtained from the standard normal cumulative distribution tables. The Sen's method is a consistent nonparametric estimator for the coefficient of a linear regression (trend magnitude),

Table 5

Seasonal distribution (\%) of regional mean annual erosivity for the whole region and the three zones.

\begin{tabular}{lcll}
\hline Climate zone & Spring & Summer & Autumn \\
\hline Arid zone & 10.5 & 78.2 & 11.1 \\
Semi-arid zone & 9.7 & 76.1 & 13.0 \\
Sub-humid zone & 8.4 & 76.0 & 14.9 \\
The whole region & 9.2 & 76.7 & 13.6 \\
\hline
\end{tabular}


i.e., the slope measured as a change in unit time (Sen, 1968). The change rate in this study was expressed in a percentage of the slope value as the mean erosivity of observation years.

The $Z$ value and the change rate of annual erosivity were estimated for each of the 237 stations with homogenous rainfall records using the MAKESENS. The estimated $Z$ values at each site were imported into ArcGIS, and then interpolated using the IDW method to reveal the spatial variation of trends.

\section{Results}

\subsection{Model validation results}

To determine the coefficient $c$ in Eq. (4), two rainfall erosivity values, EI and $(\mathrm{EI})_{60}$, were calculated for each of the selected 599 storms from 30 - and 60-min interval rainfall data, respectively. The results were presented in Fig. 3a, indicating that the $(E I)_{60}$ value was 8-$2094 \mathrm{MJ} \mathrm{mm} \mathrm{ha}^{-1} \mathrm{~h}^{-1}$, systematically lower than the EI value of 19-3234 MJ mm ha ${ }^{-1} \mathrm{~h}^{-1}$. Compared to the mean EI value of all storms ( $351 \mathrm{MJ} \mathrm{mm} \mathrm{ha}{ }^{-1} \mathrm{~h}^{-1}$ ), the mean $(\mathrm{EI})_{60}$ value (206 MJ mm ha-1 $\mathrm{h}^{-1}$ ) was underestimated by $43 \%$. This systematic error was mainly caused by the bias error in the maximum 30-min rainfall intensity I, as the value of I for all storms from 60 -min data was underrated, averagely by $39 \%$, while the total energy E was slightly underestimated by only 3\%. By linear regression, we obtained the regression slope, i.e., the coefficient $c$ as $1.793\left(R^{2}=0.95\right)$. This slope value is close to the results obtained by Yin et al. (2007) with breakpoint data taken from continuous rain gauge charts, e.g., the value was 1.811 at Zizhou station in the semi-arid northern Shaanxi of our study area. Adjusted with this $c$ value, the storm's erosivity from 60-min rainfall data was greatly improved (Fig. 3b), with the absolute error (MRAE) decreased to $10.7 \%$ from $32.6 \%$, and the root mean square error (RMSE) decreased to $7.0 \mathrm{MJ} \mathrm{mm} \mathrm{ha}{ }^{-1} \mathrm{~h}^{-1}$ from 18.1 $\mathrm{MJ} \mathrm{mm} \mathrm{ha} \mathrm{m}^{-1} \mathrm{~h}^{-1}$.

Taking 1.793 for the coefficient $c$, the annual erosivity during 1981-1988 was computed using Eq. (4) from 60-min rainfall data for the 13 representative stations, used to evaluate the estimated results with Eq. (1) from daily rainfall. The validation results were shown in Table 3. For the mean annual erosivity of 8 years, a linear regression indicated that both values at the 13 sites were highly correlated $\left(R^{2}=\right.$ 0.96 ) with the slope of 0.997 , close to 1 . The mean bias error (MRBE) was between -15.8 and $14.6 \%$ at 10 sites, and $21.7-30.7 \%$ at 3 sites. For the yearly erosivity, the predicted value from daily rainfall data was well related to that from $60-\mathrm{min}$ data $\left(\mathrm{R}^{2}=0.82-0.97\right)$ at the stations except Xiangride, but the MRAE and RMSE were rather big (Table 3 ). In general, the erosivity predicted from the daily model was plausible for most sites.

\subsection{Spatial variation in annual rainfall erosivity}

The mean annual erosivity at the 298 stations was between 2 and $4098 \mathrm{MJ} \mathrm{mm} \mathrm{ha}{ }^{-1} \mathrm{~h}^{-1}$, and was less than $500 \mathrm{~mm} \mathrm{ha}^{-1} \mathrm{~h}^{-1}$ in $65 \%$ of the region, showing a zonal variation characteristic and an increasing trend from northwest to southeast (Fig. 4). The erosivity was significantly smaller, normally below $100 \mathrm{MJ} \mathrm{mm} \mathrm{ha}{ }^{-1} \mathrm{~h}^{-1} \mathrm{a}^{-1}$ in the arid northwestern part, while evidently larger, generally above $1000 \mathrm{MJ} \mathrm{mm} \mathrm{ha}{ }^{-1} \mathrm{~h}^{-1} \mathrm{a}^{-1}$ in the sub-humid eastern part including the most of the Loess Plateau. In other parts including the Tibet Plateau and the north central Inner Mongolia Plateau, the erosivity was mostly between 100 and $500 \mathrm{~mm} \mathrm{ha}{ }^{-1} \mathrm{~h}^{-1} \mathrm{a}^{-1}$. For the whole region, the regional average was $794 \mathrm{MJ} \mathrm{mm} \mathrm{ha}{ }^{-1} \mathrm{~h}^{-1} \mathrm{a}^{-1}$, and for the arid, semi-arid and sub-humid zone, it was 97, 407 and $1372 \mathrm{MJ} \mathrm{mm} \mathrm{ha}{ }^{-1} \mathrm{~h}^{-1} \mathrm{a}^{-1}$, respectively. Based on the term of erosivity density (Forster, 2004), we calculated the ratio of erosivity to rainfall and found that it increased from the arid to sub-humid zone with an increase of annual rainfall (Table 4).

\subsection{Seasonal and annual variation in rainfall erosivity}

The rainfall erosivity showed a great seasonal and annual variation. Influenced by the monsoon climate, the erosivity was highly concentrated in summer season from June to August. For the whole region, the mean summer erosivity occupied $76.7 \%$ of the annual total, and for the arid, semi-arid and sub-humid zones, it covered 78.2, 76.1 and $76.0 \%$, respectively, showing a rather similar seasonal distribution in the three zones (Table 5). As rainstorms did not fall in winter and seldom occurred in spring, the erosivity showed a great monthly variation, with the maximum erosivity generally occurred in July or August in the semi-arid and sub-humid zones, and in June or July in the arid zone (Fig. 5). A trend analysis with the Mann-Kendall revealed that the proportion of summer erosivity for the whole region tended to decrease from 1961 to 2012 ( $Z=-1.55)$.

Annual variation of rainfall erosivity (CV) at site level varied from 32.4 to $491.3 \%$ across the region, generally decreased from northwest to southeast (Fig. 6). In the arid zone where erosive rainfall events occurred only in few years, the CV was markedly greater, mostly exceeding $110 \%$. In the semi-arid zone, the CV ranged $40-160 \%$, generally between 50 and $100 \%$ at most sites. In the sub-humid zone, the CV was much lower, mostly less than $60 \%$. For the entire region and the three zones, the mean annual erosivity also showed an apparent variation among years, even among the three-years moving averages (Fig. 7). The mean erosivity in the entire region was 511 to $1200 \mathrm{MJ} \mathrm{mm} \mathrm{ha} \mathrm{m}^{-1} \mathrm{~h}^{-1} \mathrm{a}^{-1}$ during $1961-2012$, and the CV was $19.2 \%$, close to that of $20.1 \%$ in the semi-
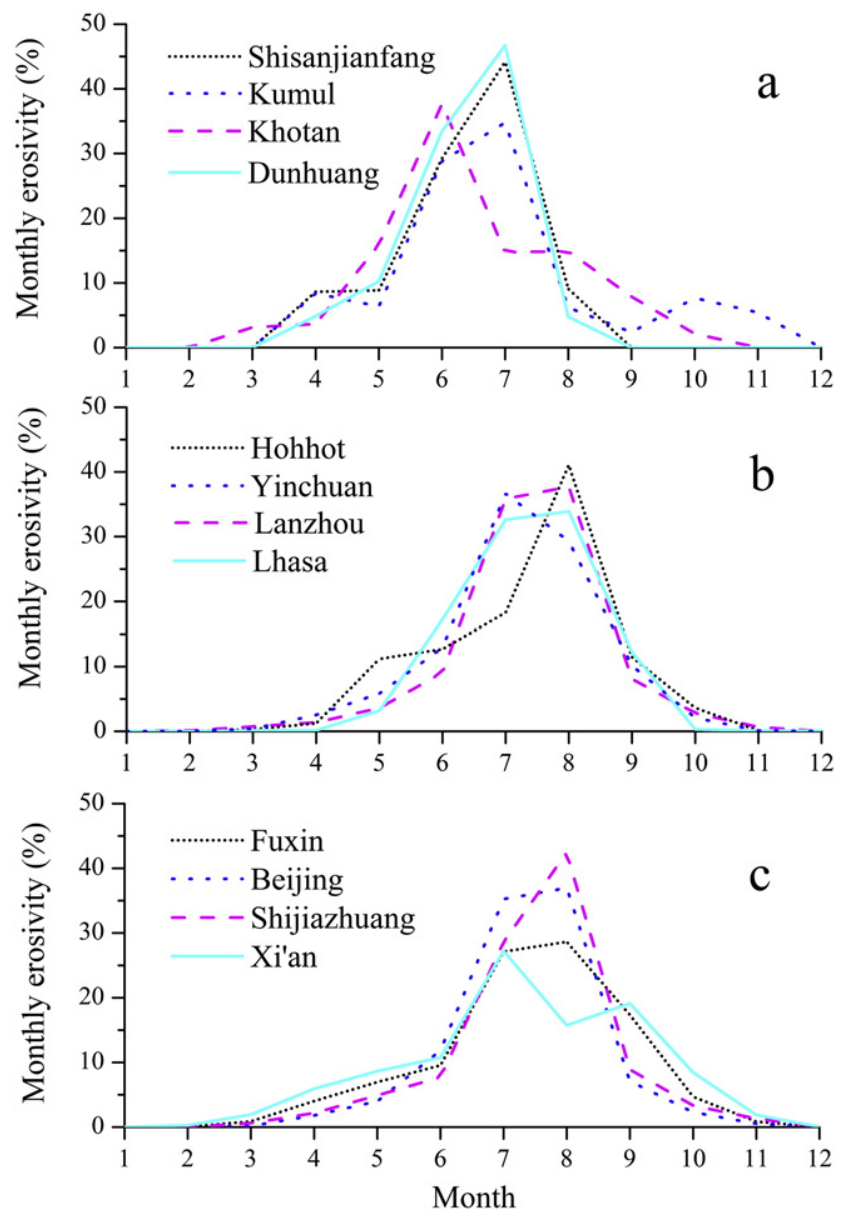

Fig. 5. Distribution (\%) of monthly rainfall erosivity at representative stations in arid zone (a), semi-arid zone (b) and sub-humid zone (c). The annual precipitation at the selected stations (for locations see Fig. 4.) was 33-41 mm in the arid zone, $192-432 \mathrm{~mm}$ in the semi-arid zone, and 495-562 $\mathrm{mm}$ in the sub-humid zone. 


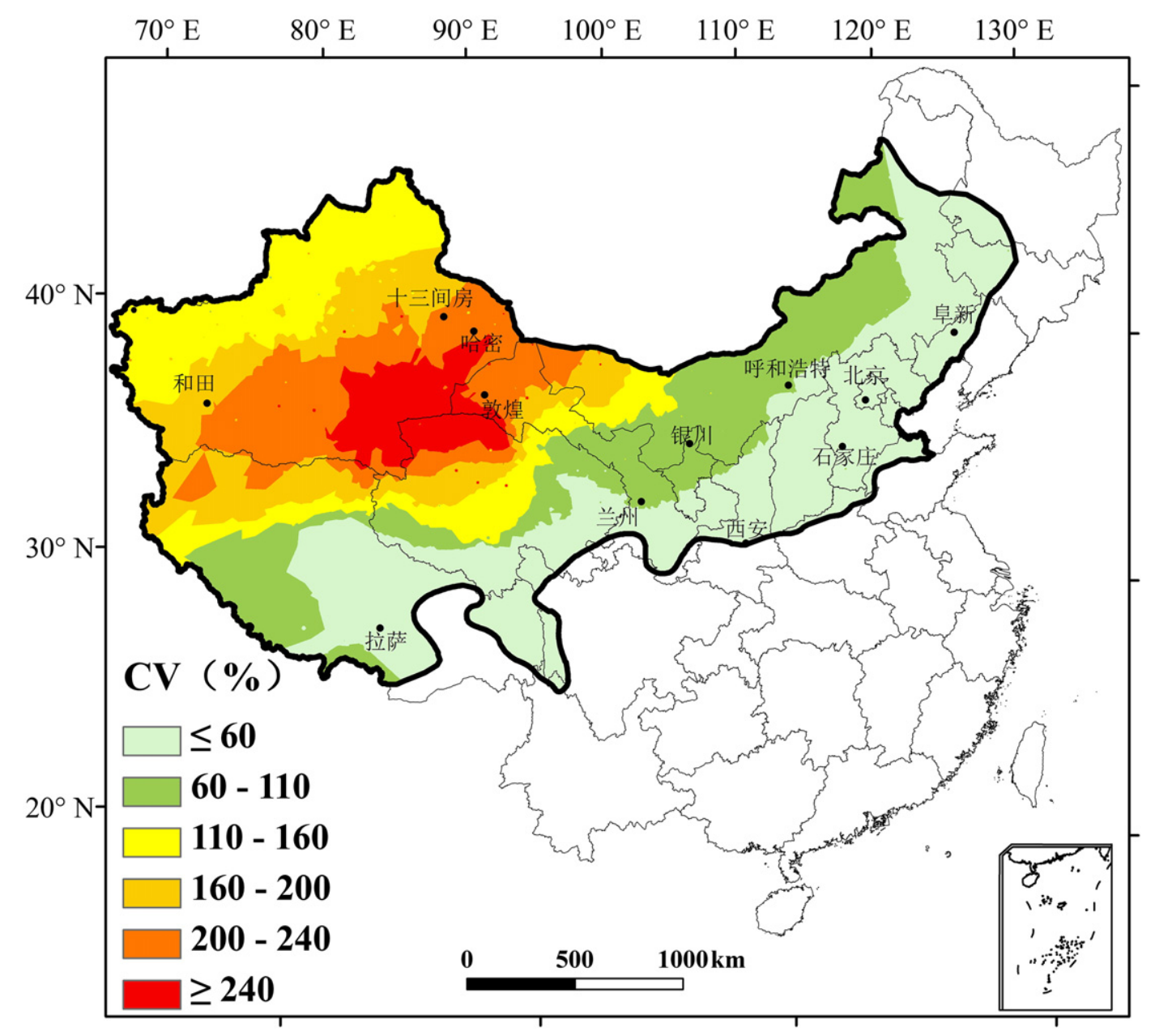

Fig. 6. Spatial distribution of relative variability (CV) of annual erosivity in the study area.

arid zone and $20.6 \%$ in the sub-humid zone, but much lower than that of $35.7 \%$ in the arid zone.

\subsection{Trend and change rate in annual rainfall erosivity}

The $\mathrm{Z}$ test value of annual rainfall erosivity during 1961-2012 was between -2.47 and 4.06 for the 237 stations. A total of 134 stations showed a positive $Z$ value and 103 a negative value. A spatial statistics with ArcGIS indicated that the stations in the arid zone mostly had a positive $Z$ value, while in the sub-humid zone a negative value, demonstrating a distinct regional difference in the direction of possible trends. In the semi-arid zone, the number of stations with a positive and negative $Z$ value did not show an apparent difference. A further analysis (Table 6) indicated that the absolute $Z$ value at 126 stations was below the value of 0.675 at the 0.5 significance level, implying that the possibility of a trend presence was below $50 \%$. At 24 (10) stations, the absolute $Z$ value exceeded the threshold value of 1.645 at the 0.1 significance level, indicating a significant increase (decrease) trend in annual erosivity. At 32 (45) stations, the absolute $Z$ value was $0.675-1.645$, showing a non-significant increase (decrease) trend at the 0.5 to 0.1 significance level. At the 24 (10) stations, the change rate of annual erosivity was 2.2 to $10.1 \%$ ( -2.6 to $-7.3 \%)$ per decade, and at the 32 (45) stations, it was 6.6 to $26.3 \%$ ( -5.5 to $-9.5 \%)$ per decade.

Fig. 8 indicated that in the majority (68.5\%) of China's dryland region, no trend was detected for the annual erosivity at the above $50 \%$ confidence level, as the absolute $Z$ value was less than 0.675 . In $21.1 \%$ of the region, the annual erosivity showed a non-significant increase trend $(Z=0.675-1.645)$, and in $10.0 \%$ a non-significant decrease trend ( $\mathrm{Z}=-0.675$ to -1.645$)$. A statistically significant upward and downward trend was observed only in a limited area, occupying $4.6 \%$ and $0.4 \%$ of the region, respectively (Table 6 ). The trend occurrence showed a highly concentrated distribution characteristic: the area with upward trends was mainly distributed in the middle part (semiarid to arid transition zone), the northern Xinjiang, and central Tibet, while the area with downward trends mainly distributed in the subhumid zone including southern Loess Plateau (Fig. 8). Few sites showed a different trend from the surroundings, probably due to the influence of high mountains.

In the arid zone, the regional mean annual erosivity was detected a significant increase trend at the 0.01 significance level $(Z=2.83)$, with an increasing rate of $7.1 \mathrm{MJ} \mathrm{mm} \mathrm{ha} \mathrm{h}^{-1} \mathrm{~h}^{-1}$ or $8.3 \%$ per decade. In the sub-humid zone, it exhibited a non-significant decline trend $(\mathrm{Z}=-1.43)$ at a decrease rate of $41.4 \mathrm{MJ} \mathrm{mm} \mathrm{ha} \mathrm{m}^{-1} \mathrm{~h}^{-1}$ or $3.3 \%$ per decade. No trend at an acceptable confidence level was found for the mean annual erosivity of the semi-arid zone $(Z=-0.29)$ and the whole region $(Z=-0.41)$. A further analysis by comparing the mean erosivity values during the first 26 years of 1961-1986 and the second of 1987-2012 indicated a similar trend. During 1987-2012, the mean annual erosivity of the arid zone ( $100 \mathrm{MJ} \mathrm{mm} \mathrm{ha} \mathrm{m}^{-1} \mathrm{~h}^{-1}$ ) markedly increased by $17.4 \%$, the sub-humid zone (1389 $\mathrm{MJ} \mathrm{mm} \mathrm{ha} \mathrm{mo}^{-1} \mathrm{~h}^{-1}$ ) decreased by $6.1 \%$, and the semi-arid zone (702 MJ mm ha ${ }^{-1} \mathrm{~h}^{-1}$ ) slightly decreased by $0.45 \%$, compared to that during $1961-1986$. For the whole region, the mean erosivity during 1987-2012 was $775 \mathrm{MJ} \mathrm{mm} \mathrm{ha}^{-1} \mathrm{~h}^{-1} \mathrm{a}^{-1}, 3.6 \%$ lower than the value of $805 \mathrm{MJ} \mathrm{mm} \mathrm{ha}{ }^{-1} \mathrm{~h}^{-1} \mathrm{a}^{-1}$ during 1961-1986. Similar change in erosivity was also found for the Loess Plateau by Elbasit et al. (2013). 

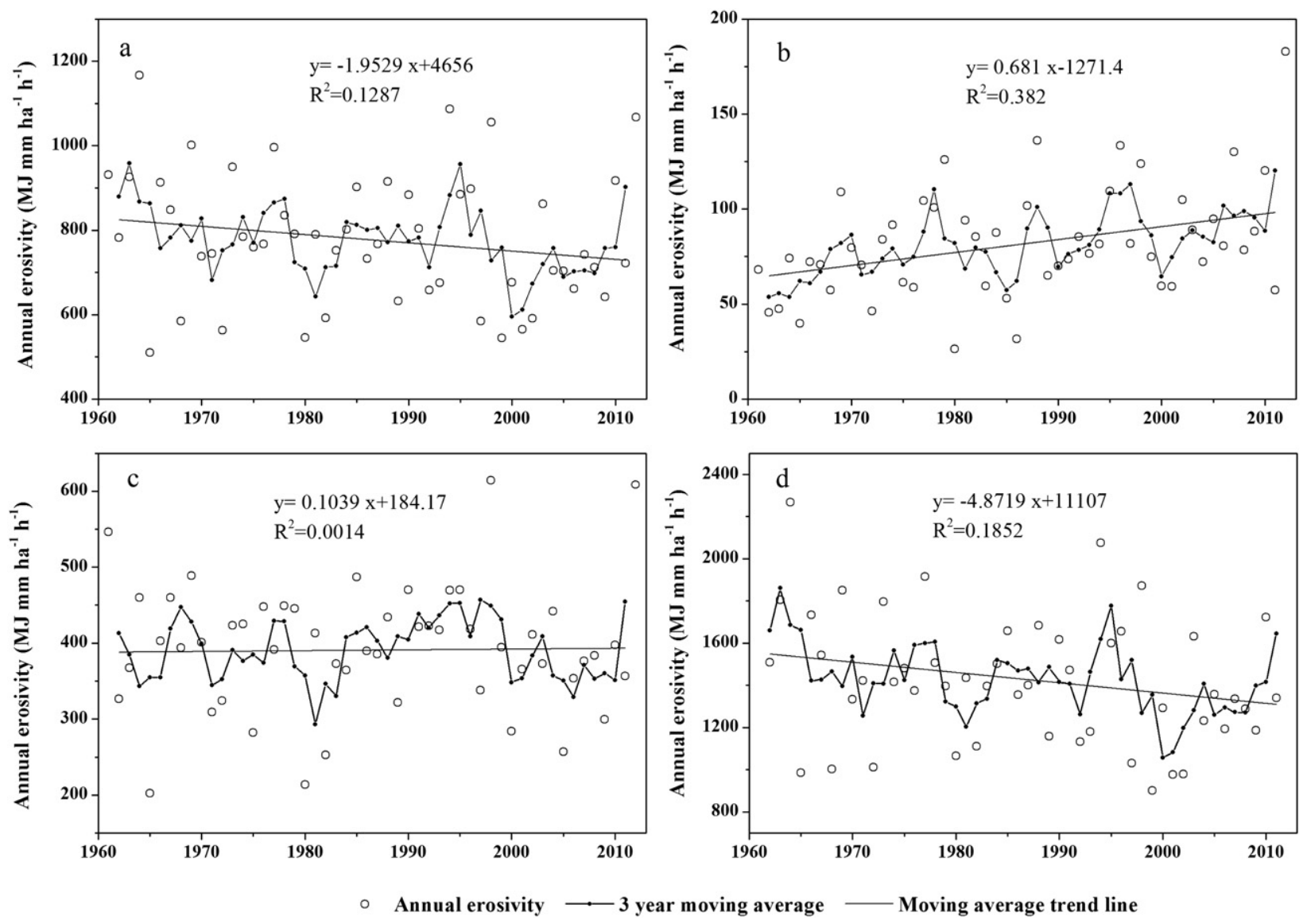

Fig. 7. Annual variation of rainfall erosivity for the whole region (a), arid zone (b), semi-arid zone (c) and sub-humid zone (d).

\section{Discussion}

This study presented the spatial, annual and seasonal variation of rainfall erosivity in China's dryland region based on the modified Richardson (1983) approach by Zhang et al. (2002). The results showed that the rainfall erosivity varied greatly over spatial, increased from the mean value below $100 \mathrm{MJ} \mathrm{mm} \mathrm{ha}{ }^{-1} \mathrm{~h}^{-1} \mathrm{a}^{-1}$ in the arid zone to $1000-$ $4098 \mathrm{MJ} \mathrm{mm} \mathrm{ha}{ }^{-1} \mathrm{~h}^{-1} \mathrm{a}^{-1}$ in the sub-humid zone. This spatial distribution was in accordance with the results of Liu et al. (2013), which indicated that the annual erosivity was generally lower than $100 \mathrm{MJ} \mathrm{mm} \mathrm{ha}{ }^{-1} \mathrm{~h}^{-1}$ in the arid region and $1000-4000 \mathrm{MJ} \mathrm{mm} \mathrm{ha}^{-1} \mathrm{~h}^{-1}$ in the sub-humid region of China. In the Loess Plateau, the annual rainfall erosivity ranged from 500 to $2000 \mathrm{MJ} \mathrm{mm} \mathrm{ha} \mathrm{m}^{-1} \mathrm{~h}^{-1}$, with the regional average of $1018 \mathrm{MJ} \mathrm{mm} \mathrm{ha}{ }^{-1} \mathrm{~h}^{-1}$, rather close to the average of $1276 \mathrm{MJ} \mathrm{mm} \mathrm{ha}{ }^{-1} \mathrm{~h}^{-1}$ during 1956-2008, as obtained by Xin et al. (2011). In the Tibet Plateau, the mean annual erosivity was generally lower than $500 \mathrm{MJ} \mathrm{mm} \mathrm{ha}{ }^{-1} \mathrm{~h}^{-1}$, similar to the results of Zhang et al. (2003). Annual rainfall erosivity varied from 679 to $2428 \mathrm{MJ} \mathrm{mm} \mathrm{ha}{ }^{-1} \mathrm{~h}^{-1}$ in Hebei province, showing a rather big difference from the values between 930 and $1667 \mathrm{MJ} \mathrm{mm} \mathrm{ha}{ }^{-1} \mathrm{~h}^{-1}$ calculated by the revised Fournier index during 1961-2000 (Men et al., 2008). The spatial variation of rainfall erosivity was largely determined by the spatial distribution of annual rainfall. Regression results using the average values at the 298 stations indicated that the mean annual erosivity was significantly related to the mean annual erosive rainfall $\left(R^{2}=0.91\right)$ and annual total rainfall $\left(R^{2}=0.58\right)$.

The erosivity showed a distinct seasonal and monthly variation because rainfall particularly the erosive rainfall mostly falls in summer season, explaining why water erosion occurs mainly in summer months in the region. With an increase in rainfall, the annual variation of rainfall erosivity decreased from the drier west to the wetter east, showing a negative relationship with annual rainfall. This was because higher rainfall is generally associated with a lower annual variation, and thus a lower variation in annual erosivity, as annual erosivity was highly related to annual rainfall. Based on the regional yearly values during 1961-2012, the regression analyses indicated that the annual rainfall erosivity was significantly related to the annual erosive rainfall $\left(\mathrm{R}^{2}=\right.$ $0.93)$, the annual total rainfall $\left(R^{2}=0.82\right)$ and the mean rainfall intensity, the ratio of annual rainfall to rain days $\left(R^{2}=0.70\right)$. Similar relationships were found at site level (Table 7 ). In general, the annual variation

Table 6

The $\mathrm{Z}$ test values and trend of annual rainfall erosivity during 1961-2012 for the 237 stations.

\begin{tabular}{|c|c|c|c|c|c|c|c|}
\hline \multirow[t]{2}{*}{ Class } & \multirow[t]{2}{*}{$Z$ value } & \multirow[t]{2}{*}{ Trend } & \multicolumn{4}{|c|}{ Number of stations } & \multirow[t]{2}{*}{$\%$ as the study area } \\
\hline & & & Arid zone & Semi-arid zone & Sub-humid zone & Total & \\
\hline 1 & $\geq 1.645$ & Significant increase & 5 & 17 & 2 & 24 & 4.6 \\
\hline 2 & $0.675-1.645$ & Non-significant increase & 7 & 14 & 11 & 32 & 16.5 \\
\hline 3 & $-0.675-0.675$ & No trend & 39 & 32 & 55 & 126 & 68.5 \\
\hline 4 & -1.645 to -0.675 & Non-significant decrease & 1 & 11 & 33 & 45 & 10.0 \\
\hline 5 & $\leq-1.645$ & Significant decrease & 0 & 3 & 7 & 10 & 0.4 \\
\hline Total & $-2.470-4.061$ & & 52 & 77 & 108 & 237 & 100.0 \\
\hline
\end{tabular}




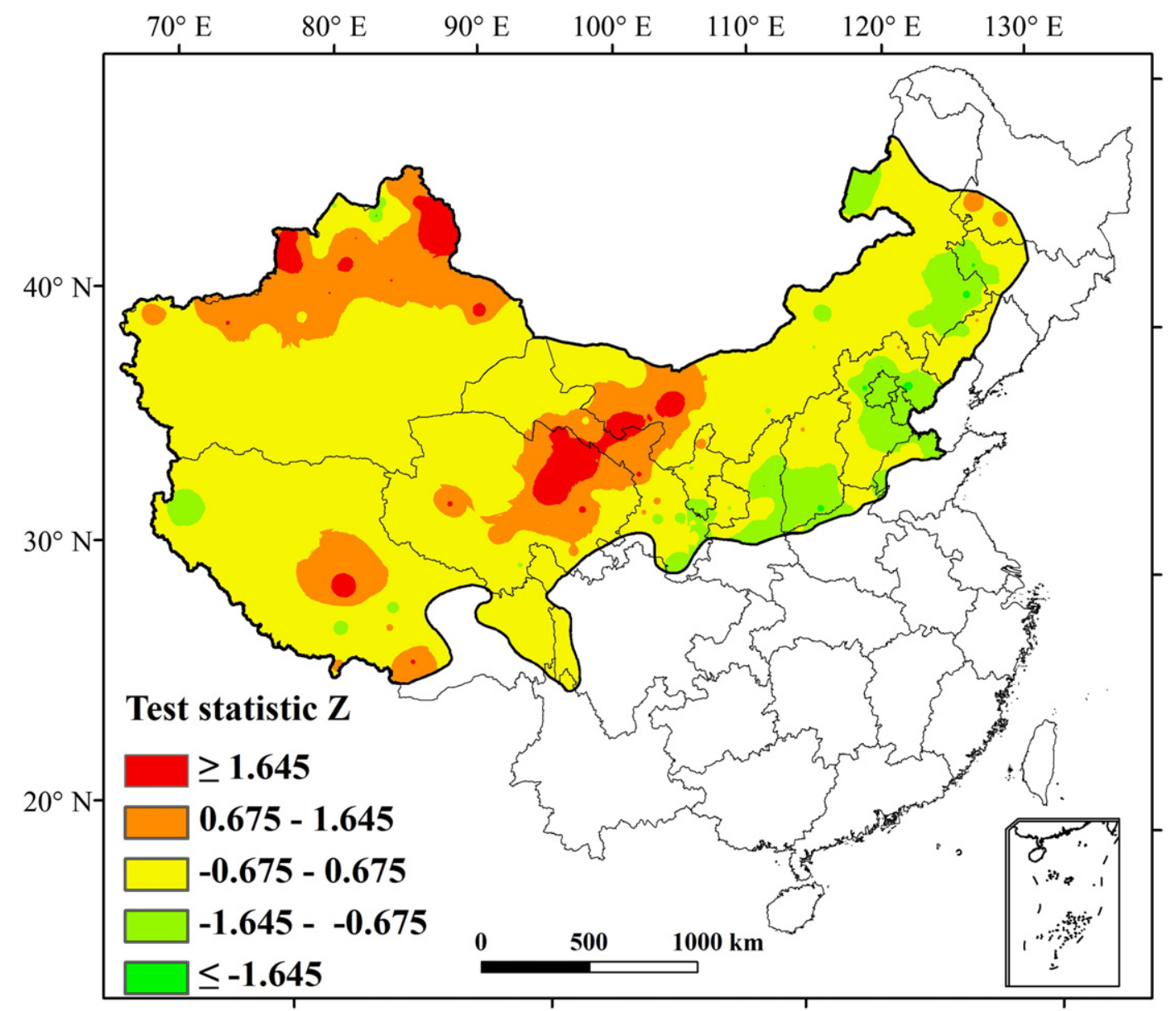

Fig. 8. Spatial variation of changing trend in the annual rainfall erosivity.

of rainfall erosivity was much bigger than that of annual rainfall, as not all rainfall events have erosive power and the erosivity is often generated by few heavy storms, particularly in the arid areas.

Most stations in the drier west part including the most of Tibet Plateau showed a positive $\mathrm{Z}$ value, while a negative value in the wetter east part including southern Loess Plateau, indicating an apparent spatial pattern in the trend occurrence of erosivity. However, a statistically significant trend in erosivity was detected only for 34 stations or about $5 \%$ of the region, and a non-significant trend was observed for 77 stations at the 50 to $90 \%$ confidence level. No statistically confidential trend can be determined for other 126 stations or in $68.5 \%$ of the region. At regional level, the mean annual erosivity was observed a significant increase trend for the arid zone, and non-significant decrease trend for the sub-humid zone, while no evidential trend for the semi-arid zone. For the whole region, the mean erosivity showed a non-significantly decreasing trend during 1961-2012 $(Z=-1.38)$, in accordance with the trend of annual erosive rainfall $(Z=-0.69)$ and annual total rainfall $(\mathrm{Z}=-0.56)$, but different from the trend of mean rainfall intensity $(Z=0.81)$ that showed a non-significantly increasing trend. Similar trends in annual rainfall erosivity during the past 50 years were found

Table 7

The coefficient of determination $\left(\mathrm{R}^{2}\right)$ of annual rainfall erosivity related to annual total and erosive rainfall, and rainfall intensity during 1961-2012 at 5 representative stations.

\begin{tabular}{llll}
\hline $\mathrm{R}^{2}$ & Annual rainfall & Erosive rainfall & Rainfall intensity \\
\hline Beijing & 0.87 & 0.90 & 0.76 \\
Taiyuan & 0.75 & 0.88 & 0.70 \\
Lanzhou & 0.55 & 0.70 & 0.57 \\
Hohhot & 0.78 & 0.84 & 0.73 \\
Linhe & 0.48 & 0.71 & 0.58 \\
\hline
\end{tabular}

by Liu et al. (2012, 2013), i.e., an increase trend in the arid north central Tibet Plateau and northern Xijiang, and a decrease trend in the sub-humid Bohai area. For the Loess Plateau as a whole, the mean erosivity was also found to decrease during 1956-2008 (Xin et al., 2011), and reduced by $10 \%$ between 1960s and 1990s (Abd Elbasit et al., 2013).

The results of this study suggest that the change in rainfall characteristics during the past 52 years could have no significant influence on water erosion risk in the most parts of the region. However, it probably had a negative impact for the arid areas, as the regional mean erosivity during 1987-2012 was evidently increased by $17.4 \%$ compared to that during 1961-1986, while a positive effect for the sub-humid part including the Loess Plateau, since it decreased by $6.1 \%$. These changes in rainfall erosivity could probably induce a corresponding slight change in the water erosion risk.

Uncertainties could be involved because the model may have rather big bias errors in the predicated erosivity for some stations particularly in the arid areas. The relief and elevation differ greatly across the region, and the impact on erosivity was not sufficiently considered. Another factor is that the stations with available data are very limited and sparsely distributed in the arid area and high mountainous areas (e.g., the Tibet Plateau), which could cause errors for the interpolated results.

\section{Conclusions}

Based on a simple daily erosivity model, this study provided insights into the spatial, inter-annual and seasonal variation of rainfall erosivity during 1961-2012 in China's dryland region. The Mann-Kendall and Sen's methods were used to detect the change trend in rainfall erosivity 
at site and regional scale, to reveal the potential impact of climate change on water erosion risk. Main findings were summarized below:

The long-term average of annual erosivity varied greatly from 2 to $4098 \mathrm{MJ} \mathrm{mm} \mathrm{ha}{ }^{-1} \mathrm{~h}^{-1} \mathrm{a}^{-1}$, with the annual variation (CV) ranging from 32.4 to $491.3 \%$ across China's dryland region. The spatial distribution of erosivity was in accordance with the spatial change of annual rainfall particularly erosive rainfall. The mean annual erosivity for the whole region was 511-1200 MJ mm ha ${ }^{-1} \mathrm{~h}^{-1}$ during 1961-2012 with the average of $794 \mathrm{MJ} \mathrm{mm} \mathrm{ha} \mathrm{m}^{-1} \mathrm{~h}^{-1}$. Rainfall erosivity had a distinct seasonal variation with about three-quarter of the annual total distributed in summer season.

During 1961-2012, total 34 stations were detected a significant trend in annual erosivity at the 0.1 significance level, comprising 10 stations with a downward trend and 24 stations with an upward trend. A total of 77 stations representing $26.5 \%$ of the study area demonstrated a non-significant trend in annual erosivity, and more than half stations with an area of $68.5 \%$ was not found a presence of trends at the confidence level of above $50 \%$. In the drier west part, the annual erosivity mostly showed a positive $Z$ value, while in the wetter east part, generally a negative value, indicating a distinct regional difference in the trend occurrence. The mean annual erosivity of the arid zone showed a significant increase trend, the sub-humid zone a non-significant decrease trend, and the semi-arid zone generally no trend. The mean erosivity during $1987-2012$ increased by $17.4 \%$ for the arid zone, and decreased by $6.1 \%$ for the sub-humid zone, $0.45 \%$ for the semi-arid zone, and $3.6 \%$ for the whole region, compared to that during 1961-1986. These results suggest that change in rainfall characteristic during past half century had no significant influence on water erosion in the majority of the region, but could probably induce an increase in the risk of water erosion in parts of the drier west and a slight decrease in parts of the wetter east.

The study contributed to the understanding of spatiotemporal variation of annual rainfall erosivity and the possible impact of changes in the rainfall characteristics associated with global warming in China's dryland area during the past half century. Uncertainties could be involved because of limited data availability and bias errors of the model.

\section{Acknowledgments}

This work was supported by the National Basic Research Program of China (2012CB955304). We are grateful to Dr. Zhao Na (Chinese Academy of Sciences) for her help in the spatial interpolation of erosivity using the HASM-SSOR model. We thank the two anonymous reviewers for their constructive comments.

\section{References}

Abd Elbasit, M.A.M., Huang, J.B., Ojha, C.S.P., Yasuda, H., Adam, E.O., 2013. Spatiotempora changes of rainfall erosivity in Loess Plateau, China. ISRN Soil Sci. 1-8.

Alexandersson, H., 1986. A homogeneity test applied to precipitation data. J. Climatol. 6 , 661-675.

Angulo-Martinez, M., Begueria, S., 2009. Estimating rainfall erosivity from daily precipitation records: a comparison among methods using data from the Ebro Basin (NE Spain). J. Hydrol. 379, 111-121.

Back, A.J., Henn, A., Oliveira, J.L.R., 2011. Heavy rainfall equations for Santa Catarina, Brazil Rev. Bras. Cienc. Solo 35, 2127-2134.

Bazzano, M.G.P., Eltz, F.L.F., Cassol, E.A., 2010. Erosivity and hydrological characteristics of rainfalls in Rio Grande (Rs, Brazil). Rev. Bras. Cienc. Solo 34, 235-244.

Beran, R., Feuerverger, A., Hall, P., 1996. On nonparametric estimation of intercept and slope distributions in random coefficient regression. Ann. Stat. 24, 2569-2592.

Bonilla, C.A., Vidal, K.L., 2011. Rainfall erosivity in Central Chile. J. Hydrol. 410, 126-133.

Brown, L.C., Foster, G.R., 1987. Storm erosivity using idealized intensity distribution. Trans. ASAE 30, 379-386.

Burn, D.H., Elnur, M.A.H., 2002. Detection of hydrologic trends and variability. J. Hydrol. $255,107-122$

Busnelli, J., Neder, L.d.V., Sayago, J.M., 2006. Temporal dynamics of soil erosion and rainfall erosivity as geoindicators of land degradation in Northwestern Argentina. Quat. Int 158, 147-161.

Ci, L.J., Wu, B., 1997. Climatic type division and the potential extent determination of desertification in China. J. Desert Res. 17, 107-111 (in Chinese).
Costa, A.C., Soares, A., 2009. Homogenization of climate data: review and new perspectives using geostatistics. Math. Geosci. 41, 291-305.

Dai, J.H., Wang, H.J., Ge, Q.S., 2012. Multiple phenological responses to climate change among 42 plant species in Xi'an, China. Int. J. Biometeorol. 57, 749-758.

Dai, J.H., Wang, H.J., Ge, Q.S., 2014. The spatial pattern of leaf phenology and its response to climate change in China. Int. J. Biometeorol. 58, 521-528.

Diodato, N., Bellocchi, G., 2009. Assessing and modelling changes in rainfall erosivity at different climate scales. Earth Surf. Process. Landf. 34, 969-980.

Elbasit, A.M.A., et al., 2013. Relationship between rainfall erosivity indicators under arid environments: case of Liudaogou basin in Chinese Loess Plateau. J. Food Agric. Environ. 11, 1073-1077.

Fan, L., Lu, C.H., Yang, B., Chen, Z., 2012. Long-term trends of precipitation in the North China Plain. J. Geogr. Sci. 22, 989-1001.

Feng, S., Fu, Q., 2013. Expansion of global drylands under a warming climate. Atmos. Chem. Phys. 13, 10081-10094.

Forster, R.G., 2004. User's reference guide: Revised Universal Soil Loss Equation Version 2 (RUSLE2). USDA-Agricultural Research Service, Washington, D.C.

Ge, Q.S., Wang, H.J., Dai, J.H., 2013. Shifts in spring phenophases, frost events and frost risk for woody plants in temperate China. Clim. Res. 57, 249-258.

Gilbert, R.O., 1987. Statistical methods for environmental pollution monitoring. Van Nostrand Reinhold Co., New York.

He, L., et al., 2014. Diverse responses of winter wheat yield and water use to climate change and variability on the semiarid Loess Plateau in China. Agron. J. 106, 1169-1178.

Huang, J., Guan, X., Ji, F., 2012. Enhanced cold-season warming in semi-arid regions. Atmos. Chem. Phys. 12, 5391-5398.

IPCC, 2013. Climate Change 2013: The Physical Science Basis. Cambridge University Press, Cambridge.

Jiang, Z.H., Huang, Q., Li, Q.X., 2008. Study of precipitation series homogeneous adjustment and their correction over China in the last 50 years. Clim. Environ. Res. 13, 67-74.

Kendall, M.G., 1975. Rank Correlation Methods. Griffin, London.

Khaliq, M.N., Ouarda, T.B.M.J., 2007. On the critical values of the standard normal homogeneity test (SNHT). Int. J. Climatol. 27, 681-687.

Lee, J.H., Heo, J.H., 2011. Evaluation of estimation methods for rainfall erosivity based on annual precipitation in Korea. J. Hydrol. 409, 30-48.

Liu, X.N., Sun, A.J., 1995. An inhomogeheity test study of annual precipitation series. Meteorol. Mon. 21, 3-6 (in Chinese)

Liu, B.T., Tao, H.P., Song, C.F., Guo, B., Shi, Z., 2012. Temporal and spatial variations of rainfall erosivity in southwest China from 1960 to 2009. Adv. Earth Sci. 27, 499-509 (in Chinese).

Liu, B.T., Tao, H.P., Song, C.F., 2013. Temporal and spatial variations of rainfall erosivity in China during 1960 to 2009. Geogr. Res. 32, 245-256 (in Chinese)

Lo, A. EI-Swaify, S.A., Dangler, E.W. 1985. Effectiveness of EI30 as an erosivity index in Hawaii soil erosion and conservation. Soil Conservation Society of America, Ankeny.

Loureiro, N.D., Coutinho, M.D., 2001. A new procedure to estimate the RUSLE EI30 index, based on monthly rainfall data and applied to the Algarve region, Portugal. J. Hydrol. $250,12-18$

Mann, H.B., 1945. Nonparametric tests against trend. Econometrica 13, 245-259.

Men, M.X., Yu, Z.R., Xu, H., 2008. Study on the spatial pattern of rainfall erosivity based on geostatistics in Hebei Province, China. Front. Agric. China 2, 281-289.

Meng, X.J., Zhang, S.F., Zhang, Y.Y., Wang, C.C., 2013. Temporal and spatial changes of temperature and precipitation in Hexi Corridor during 1955-2011. J. Geogr. Sci. 23, 653-667.

Meusburger, K., Steel, A., Panagos, P., Montanarella, L., Alewell, C., 2012. Spatial and temporal variability of rainfall erosivity factor for Switzerland. Hydrol. Earth Syst. Sci. 16, 167-177.

Petkovšek, G., Mikoš, M., 2004. Estimating the R factor from daily rainfall data in the subMediterranean climate of southwest Slovenia. Hydrol. Sci. J. 49, 869-877.

Renard, K.G., Freimund, J.R., 1994. Using monthly precipitation data to estimate the Rfactor in the revised USLE. J. Hydrol. 157, 287-306.

Renard, K.G., Foster, G.R., Weesies, G.A., McCool, D.K., Toder, D.C., 1997. Predicting soil erosion by water: a guide to conservation planning with the revised universal soil loss equation (RUSLE). U. S. Gov. Print Office, Washington DC.

Richardson, C.W., 1983. Estimation of erosion index from daily rainfall amounts. Trans. ASAE 26, 153-156.

Salmi, T., Maata, A., Antilla, P., Ruoho-Airola, T., Amnell, T., 2002. Detecting trends of annual values of atmospheric pollutants by the Mann-Kendall test and Sen's slope estimates-the Excel template application Makesens. Finnish Meteorological Institute, Helsinki, Finland.

Sen, P.K., 1968. Estimates of the regression coefficient based on Kendall's tau. J. Am. Stat. Assoc. 63, 1379-1389.

Sicard, P., Mangin, A., Hebel, P., Mallea, P., 2010. Detection and estimation trends linked to air quality and mortality on French Riviera over the 1990-2005 period. Sci. Total Environ. 408, 1943-1950.

Thornthwaite, C.W., 1948. An approach toward a rational classification of climate. Geogr. Rev. 38, 57-94.

Toreti, A., et al., 2011. A note on the use of the standard normal homogeneity test to detect inhomogeneities in climatic time series. Int. J. Climatol. 31, 630-632.

Wang, Y., Cao, M.K., Tao, B., Li, K.R., 2006. The characteristics of spatio-temporal patterns in precipitation in China under the background of global climate change. Geogr. Res. 25, 1031-1040 (in Chinese).

Wang, Z.G., Ficklin, D.L., Zhang, Y.Y., Zhang, M.H., 2012. Impact of climate change on streamflow in the arid Shiyang River Basin of northwest China. Hydrol. Process. 26, 2733-2744

Weiss, L.L., 1964. Ratio of true to fixed-interval maximum rainfall. J. Hydraul. Div. ASCE 1, $77-82$. 
Wischmeier, W.H., Simth, D.D., 1958. Rainfall energy and its relationship to soil loss. Trans. Am. Geophys. Union 39, 285-291.

Wischmeier, W.H., Smith, D.D., 1965. Predicting rainfall erosion losses from cropland east of the Rocky Mountains. USDA Agric. Handb. 282, 1-47.

Wischmeier, W.H., Simth, D.D., 1978. Predicting rainfall erosion losses - a guide to conservation planning with the universal soil loss equation. USDA Agric. Handb. 537, $1-69$.

Xiao, G.J., et al., 2013. Response to climate change for potato water use efficiency in semiarid areas of China. Agric. Water Manag. 127, 119-123.

Xie, Y., Liu, B.Y., Zhang, W.B., 2000. Study on standard of erosive rainfall. J. Soil Water Conserv. 14, 6-11 (in Chinese).

Xin, Z.B., Yu, X.X., Li, Q.Y., Lu, X.X., 2011. Spatiotemporal variation in rainfall erosivity on the Chinese Loess Plateau during the period 1956-2008. Reg. Environ. Chang. 11, 149-159.

Yao, Y.B., et al., 2012. Impacts of climate change on growth and yield of winter wheat in the semi-humid region of the Loess Plateau. Acta Ecol. Sin. 32, 5154-5163 (in Chinese).

Yao, Y.B., et al., 2013. Change of terrestrial surface drought and wet conditions on the Loess Plateau (China) during the last half-century. J. Arid Land 5, 15-24.

Yin, S., Xie, Y., Nearing, M.A., Wang, C., 2007. Estimation of rainfall erosivity using 5- to 60minute fixed-interval rainfall data from China. Catena 70, 306-312.
Yu, B., Rosewell, C.J., 1996. An assessment of a daily rainfall erosivity model for New South Wales. Aust. J. Soil Res. 34, 139-152.

Yue, T.X., 2010. Surface Modelling: High Accuracy and High Speed Methods. CRC Press, Boca Raton, FL.

Yue, T.X., Du, Z.P., Liu, J.Y., 2004. High accuracy surface modeling (HASM2). Prog. Nat. Sci. $14,83-89$.

Zhang, W.B., Xie, Y., Liu, B.Y., 2002. Rainfall erosivity estimation using daily rainfall amounts. Sci. Geogr. Sin. 22, 705-711 (in Chinese)

Zhang, W.B., Xie, Y., Liu, B.Y., 2003. Spatial distribution of rainfall erosivity in China. J. Mt Sci. 21, 33-40 (in Chinese).

Zhang, Y.Y., Zhang, S.F., Xia, J., Dong, H., 2013. Temporal and spatial variation of the main water balance components in the three rivers source region, China from 1960 to 2000. Environ. Earth Sci. 68, 973-983.

Zhao, H.R., 2013. Temporal and spatial variations and transition of precipitation in China during 1960-2010. Trop. Geogr. 33, 414-419 (in Chinese).

Zhu, Q., Chen, X.W., Fan, Q.X., 2011. A new procedure to estimate the rainfall erosivity factor based on Tropical Rainfall Measuring Mission (TRMM) data. Sci. China Technol. Sci. 54, 2437-2445. 